\title{
Letter \\ Myocardial injury associated with hyperinflation of the lung
} Michael Eisenhut

Luton and Dunstable Hospital, Lewsey Road, Luton, UK

Correspondence: Michael Eisenhut, michael_eisenhut@yahoo.com

Published: 30 April 2007

This article is online at http://ccforum.com/content/11/2/412

(c) 2007 BioMed Central Ltd

See related research by Kredel et al., http://ccforum.com/content/11/1/R13
Critical Care 2007, 11:412 (doi:10.1186/cc5738)

Previous studies found that patients with acutely elevated intrapulmonary pressure resulting from bronchospasm [2] and severe respiratory syncytial viral lung disease leading to hyperinflation [3] exhibited evidence of myocardial injury, such as elevated cardiac troponin levels; this was probably due to strain imposed on the right ventricle by pulmonary hypertension. Ventricular strain has previously also been associated with elevated hyaluronate levels [4]. The increase in hepatic neutrophils may be due to a hyperoxia-induced increased inflammatory response found in patients with increased positive end-expiratory pressure and fractional inspired oxygen $\left(\mathrm{FiO}_{2}\right)$ [5]. Future studies need to use specific markers for myocardial injury such as cardiac troponin $\mathrm{T}$ in order to discriminate between myocardial and hepatic injury associated with the various ventilation strategies.

\section{Authors' response}

Markus Kredel and Christian Wunder

We thank Dr Eisenhut for his comments. He raises the issue of whether myocardial injury was the origin of the increased serum AST levels observed in animals treated with the recruitment manoeuvre (RM). Although we did not measure troponin $\mathrm{T}$ levels, there was no evidence for myocardial injury during the performed RM. Haemodynamic variables, as shown in Table 1 of our report [1], and mixed venous oxygen saturation (data not shown) were comparable in the two groups at all time points. In addition, the expected and observed increase in central venous pressure and decrease in cardiac output during the RM did not result in differences in pulmonary artery pressure. This casts right ventricular strain into doubt.

In addition to nonspecific transaminases and hyaluronic acid, bilirubin was also elevated in the systemic circulation in the group undergoing the RM. High positive end-expiratory pressure is known to be an independent risk factor for liver dysfunction, as indicated by hyperbilirubinemia [6].

Regarding the histologic examination, Dr Eisenhut speculates that the increase in liver neutrophils might be due to hyperoxia. The arterial oxygen tension $\left(\mathrm{PaO}_{2}\right) / \mathrm{FiO}_{2}$ ratio (Table 2 in our report [1]) was improved in the RM group, but $\mathrm{PaO}_{2}$ levels were even lower after $\mathrm{FiO}_{2}$ was reduced to 0.4 following the RM. In contrast, in the animals that did not receive the $\mathrm{RM}$ the $\mathrm{FiO}_{2}$ was fixed at 1.0, despite improvement in $\mathrm{PaO}_{2}$ during the trial. In addition, McClintock and coworkers [5], examining urinary nitric oxide excretion in a subgroup of patients included in the ARDS-Network study, did not address hyperoxia-induced inflammatory responses. Nevertheless, we cannot exclude the possibility that the inflammatory reaction in the liver was a remote effect of ventilation. 


\section{Competing interests}

The author declares that they have no competing interests.

\section{References}

1. Kredel M, Muellenbach RM, Brock RW, Wilckens HH, Brederlau $\mathrm{J}$, Roewer N, Wunder C: Liver dysfunction after lung recruitment manoeuvres during pressure controlled ventilation in experimental acute respiratory distress. Crit Care 2007, 11: R13.

2. Angulo F, Alvarado $\mathrm{Y}$, Chokesuwattanaskul W, Roongsritong C: Troponin I elevation in a patient with acute severe bronchospasm. Am J Med Sci 2005, 329:320-321.

3. Eisenhut M, Thorburn $\mathrm{K}$, Ahmed T: Transaminase levels in ventilated children with respiratory syncytial virus bronchiolitis. Intensive Care Med 2004, 30: 931-934.

4. Li G, Yan OB, Wei LM: Serum concentrations of hyaluronic acid, procollagen type II NH2-terminal peptide, and laminin in patients with chronic congestive heart failure. Chin Med Sci J 2006, 21:175-178.

5. McClintock DE, Ware LB, Eisner MD, Wickersham N, Thompson BT, Matthay MA, and the National Heart, Lung and Blood Institute ARDS Network: Higher urine nitric oxide is associated with improved outcomes in patients with acute lung injury. $\mathrm{Am} J$ Respir Crit Care Med 2007, 175:256-262.

6. Brienza N, Dalfino L, Cinnella G, Diele C, Bruno F, Fiore T: Jaundice in critical illness: promoting factors of a concealed reality. Intensive Care Med 2006, 32:267-274. 